\title{
Migration and Hybrid Political Regimes: Navigating the Legal Landscape in Russia
}

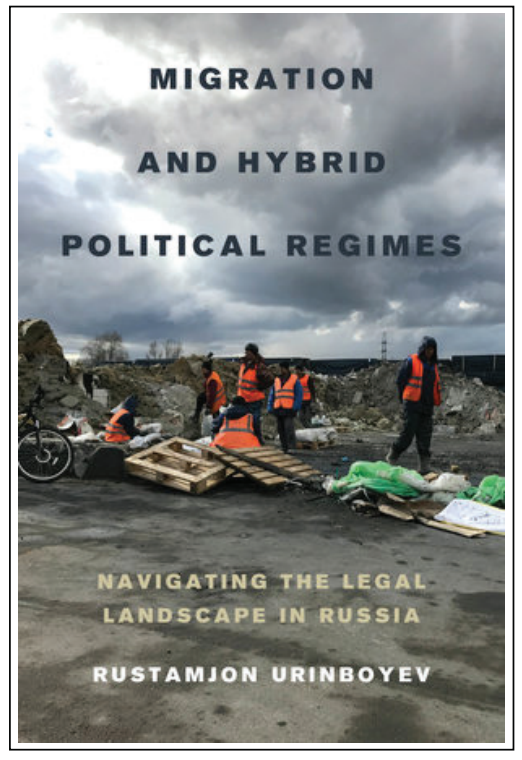

Rustam Urinboyev

Oakland: University of California Press 2021 169 sidor. ISBN 9780520299573 (paperback) | ISBN 9780520971257 (epub)

Recenserad av Anna-Liisa Heusala [fil.dr i samhällsvetenskap, universitetslektor i ryska och eurasiska studier, Alexanderinstitutet, Helsingfors universitet, anna-liisa.heusala@helsinki.fi]

Denna bok är resultatet av en mångsidig etnografisk studie som författaren Rustam Urinboyev utfört mellan 2014 och 2018, och adresserar de svårigheter som personer i jakt på ett bättre liv upplever på grund av global ojämlikhet, ekonomiska och sociala intressekonflikter samt svaga institutioner. Författaren har genom formella och informella intervjuer, med hjälp av sociala nätverkssajter och deltagande observationer samlat in ett omfattande material. I materialet beskrivs de interna och externa resor som företas av centralasiatiska medborgare som migrerar mellan Ryssland och sina hemländer. Författaren gör en beskrivande tolkning grundad på fallstudier för att visa på samspelet mellan migranternas skicklighet och det ryska migrationssystemets sociala struktur. Som ett etnografiskt verk om migration mellan det postsovjetiska Centralasien och Ryssland bygger Urinboyevs bok vidare på det arbete som utförts av Sergej Abasjin, Madeleine Reeves och Agnieszka Kubal, forskare som alla har analyserat migranters upplevelser och det ryska migrationssystemet på senare tid.

Författaren driver tesen att migration mellan hybridregimer fortsätter att vara en vit fläck inom migrationsforskning. Hans avsikt är att tillämpa en rättslig pluralism 
(legal pluralism) på en icke-västerländsk kontext med hybridregimer. Detta perspektiv grundas på idén att lagstiftning (i skrift) inte är enhetlig eller den enda källan till normer och makt i ett samhälle, utan istället bör förstås som "levande rätt», en mångsidig konstruktion med multikulturella och transnationella inslag. På ett liknande sätt bör forskningen även fokusera på en anpassning till informella rättssystem som ligger utanför nationell invandringslagstiftning, politik och formella institutioner.

Författarens kontaktnät i Ferganadalen, som han själv kommer från, har underlättat för honom att bedriva sin forskning och komma åt de studerade personernas bakgrundshistorier, åtminstone männens. Avsaknaden av kvinnors personliga livsberättelser gör dock boken till ett fönster för manliga migranters upplevelser. Ett initierat perspektiv är otvivelaktigt en fördel för att förstå den flerskiktade innebörden i migranternas egna upplevelser. Närheten till de personer som ingår i studien ger emellertid upphov till frågor om den initierade personens position och reflexivitet. De metodologiska konsekvenserna av detta berörs inte av författaren. Den främsta styrkan i hans arbete är de detaljerade beskrivningarna av nätverken, metoderna och tankesätten kopplade till informalitet och migration.

För de läsare som är intresserade av en analys av den ryska hybridregimen och den teoretiska nyttan av detta koncept fungerar boken som en inledande diskussion. En av slutsatserna är att administrativ korruption inte bara är en avvikelse från ett korrekt genomförande av lagar och förordningar. Istället bekräftas här att det är ett institutionaliserat tillvägagångssätt $i$ det ryska migrationssystemet. För att visa på hybridregimens betydelse för sådana metoder hade det varit lämpligt med en mer utarbetad definition av själva begreppet. Den nuvarande definitionen av hybridregim fungerar främst som bakgrund för bokens berättelse. Författaren förutsätter att det finns renodlade typer av regimer: en där rättsstatsprincipen tillämpas fullt ut och på ett framgångsrikt sätt, medan den andra är en korrupt hybridregim som fullständigt åsidosätter samma princip. En kritisk läsare kan hävda att rättsstatsprincipen inte är ett slutresultat utan snarare en föränderlig process, med skillnader mellan demokratier, organisationer, samhällen och enskilda fall. En stats förmåga att implementera lagstiftningen, en av rättsstatens grundläggande komponenter, ifrågasätts ständigt i gamla demokratier. Problemen kopplade till migranternas erfarenheter av skuggekonomin (shadow economy) - ett begrepp som används i boken - kan ha många motsvarigheter såväl i icke-västerländska som i västerländska samhällen.

Det andra viktiga begreppet, migranternas aktörskap (migrant agency), definieras som migranternas förmåga att använda informella vägar på ett kreativt sätt för att undvika hinder i form av migrationslagstiftning och migrationspolitik. Författaren stöder idén att den befintliga forskningen främst har fokuserat på migranter som föremål för politik och lagstiftning, och att den har förbisett deras proaktiva och gatusmarta beteende vid studier av rättslig integrering och anpassning. Författaren önskar bidra till teoretiseringen av migranters rättsliga anpassning genom att presentera ett välmotiverat perspektiv av rättslig pluralism, men utvecklar inte användningen av detta koncept senare i boken. Författarens arbete bidrar därför framför allt 
med en utförlig etnografisk beskrivning av informella metoder i samband med postsovjetisk, centralasiatisk migration till Ryssland. Fallstudierna av det transnationella livet skapar en bild där både byarnas traditioner och de senaste mobiltelefonerna bidrar till migranternas överlevnad i Ryssland. De särskilda förutsättningarna för att delta i Rysslands skuggekonomi och hur detta påverkar hembygden i Centralasien är viktig läsning för studenter som fördjupar sig i postsovjetiska Eurasien. De personliga livshistorierna ger djup åt berättelsen.

Den centralasiatiska migrationen till Ryssland, och den uzbekiska migrationen som en del i detta flöde, är en stark socioekonomisk kraft i både ursprungsländerna och i Ryska Federationen. Migrationen är en del av de globala processer som formar regionen ekonomiskt, kulturellt och strategiskt. Jag rekommenderar den här boken till alla som vill lära sig mer om globala migranters erfarenheter i dagens värld. Den bidrar även till en mer allmän diskussion om hur vi kan använda migrationsteorier i framtida forskning. Dokumentation och analys av personliga livsberättelser och erfarenheter är kanske det sätt på vilket forskningen kan ge migranterna en röst, vilket är ett av bokens syften. Boken kommer att fungera som referenspunkt för framtida studier om utvecklingen av rättsliga och administrativa processer och mänsklig säkerhet i Eurasien. 